\title{
Narrative Review: Implementation of Pharmaceutical Care on Hypertension in Indonesia
}

\section{(Tinjauan Naratif: Penerapan Asuhan Kefarmasian pada Hipertensi di Indonesia)}

\author{
Sarmalina Simamora*, Widyan Muchzadi Akbar, Sonlimar Mangunsong \\ Program Studi DIII Farmasi, Poltekkes Kemenkes Palembang, South Sumatera, Indonesia. \\ *E-mail: sarmalina@poltekkespalembang.ac.id
}

Article Info:

Received: 26 October 2021

in revised form: 27 November 2021

Accepted: 10 December 2021

Available Online: 12 December 2021

Keywords:

Hypertension

Pharmaceutical Services

Public Health Centre

Hospital.

Corresponding Author:

Sarmalina Simamora

Program Studi DIII Farmasi

Poltekkes Kemenkes Palembang

South Sumatera

Indonesia

email:

sarmalina@poltekkespalembang.ac.id

\begin{abstract}
Background: In the past, patient care was not a pharmacy orientation. Several developed countries have applied pharmaceutical care in the treatment of hypertension for years. However, the gap is still there. In Indonesia, the government issued guidelines of the care of hypertension medications for the first time in 2006. The stages are that pharmacists carry out assessments, preparing pharmaceutical service plans, and then implementation and monitoring. This study aims to examine the application of pharmaceutical care on hypertension based on various articles published in Indonesia. Methods: This research is nonexperimental research with a narrative review design. Articles were selected using the keywords pharmaceutical care, pharmacy care, pharmaceutical care and hypertension. Articles were collected from national journals with the number of articles reviewed was 13 articles from 2014 to 2019. Results: The application of pharmaceutical care on hypertension in Indonesia has been carried out by pharmacists, especially in hospitals. The implementation stages are more focused on implementation and monitoring. Only $15 \%$ carried out the plan, and almost no carried out the assessment. Conclusion: The application of pharmacy on hypertension has not fully complied with the guidelines. Pharmacists have not assessed when they will start pharmaceutical care. Intervention is carried out with various models, such as leaflets, short messages sent and counselling. The results were monitored on the patient's knowledge, compliance and blood pressure. There is an improvement in result, although there is also not.
\end{abstract}

Copyright (C) 2019 JFG-UNTAD

This open access article is distributed under a Creative Commons Attribution (CC-BY-NC-SA) 4.0 International license.

How to cite (APA $6^{\text {th }}$ Style):

Simamora, S., Akbar, W. M., Mangunsong, S. (2021). Narrative Review: Implementation of pharmaceutical care in hypertension in Indonesia. Jurnal Farmasi Galenika: Galenika Journal of Pharmacy (e-Journal), 7(3), $260-270$. doi:10.22487/j24428744.2021.v7.i3.15662 


\begin{abstract}
ABSTRAK
Latar Belakang: Pelayanan kefarmasian pada masa lalu belum ber-orientasi pada pasien. Beberapa negara maju telah menerapkan asuhan kefarmasian dalam pengobatan hipertensi selama bertahun-tahun. Namun demikian, kesenjangan masih ada. Di Indonesia, pedoman asuhan kefarmasian pada hipertensi pertama kali diterbitkan oleh pada tahun 2006. Tahapannya adalah, apoteker melaksanakan penilaian, penyusunan rencana pelayanan kefarmasian, intervensi dan monitoring. Tujuan penelitian ini adalah menelaah penerapan asuhan kefarmasian pada penyakit hipertensi yang ada di berbagai artikel yang terbit di Indonesia. Metode: Penelitian ini adalah penelitian non-eksperimental dengan rancangan narrative review. Artikel diseleksi dengan menggunakan kata kunci pharmaceutical care, pharmacy care, asuhan kefarmasian dan hipertensi. Artikel ditelusuri di jurnal nasional. Jumlah yang ditelaah sebanyak 13 artikel dari tahun 2014 sampai 2019. Hasil: Penerapan asuhan kefarmasian pada penyakit hipertensi di Indonesia telah dilaksanakan oleh Apoteker, terutama di rumah sakit. Pada tahapan penerapannya lebih fokus pada intervensi dan pemantauan. Hanya 15\% yang melaksanakan penyusunan rencana dan hampir tidak ada yang melakukan assesmen. Kesimpulan: Penerapan asuhan kefarmasian pada hipertensi belum sepenuhnya sesuai pedoman. Apoteker belum melakukan penilaian saat akan memulai penerapannya. Kegiatan intervensi dilakukan dengan berbagai model, seperti pemberian leaflet, pengiriman pesan singkat dan konseling Pemantauan hasil dilakukan terhadap pengetahuan, kepatuhan dan tekanan darah pasien. Hasilnya ada perbaikan, walaupun ada juga yang tidak. .
\end{abstract}

Kata kunci: Hipertensi, Pharmaceutical Care, Puskesmas, Rumah Sakit.

\title{
INTRODUCTION
}

Blood pressure is the force that occurs when blood flows into the arteries, which are the main blood vessels in the body. Hypertension occurs when blood pressure is too high. Hypertension is a chronic disease with a high prevalence in the world and Indonesia. The results of Basic Health Research (Riskesdas) on 2018 showed that the national hypertension prevalence rate in the population aged over 18 years is $34.11 \%$. This prevalence is higher than the prevalence in 2013 which was $25.8 \%$. (Anonim, 2006). Pharmaceutical service is a direct and responsible service to patients. Pharmacists, assisted by pharmaceutical technical personnel, deliver drugs to patients, either on a prescription basis or not. The purpose of using the drug is to achieve definite results in treatment. In addition, for chronic diseases, the use of drugs is expected to improve the patient's quality of life (Anonim, 2006). Hypertension requires consistent, regular treatment, and is monitored and evaluated for its outcome. To support the management of hypertension, apart from doctors, nurses and nutritionists, the active role of pharmacists is also needed. The use of drugs in the long term can cause various problems. Pharmacists can play an active role so that patients get optimal outcomes and avoid drug-related problems. One approach that can be applied by pharmacists is through pharmaceutical care. The definition of pharmaceutical care is that pharmacists can identify, resolve and prevent problems that may arise due to drug use. In the implementation, it combines the expertise of pharmacists in monitoring and counselling patients (Upadhyay and Ooi 2018)

In Indonesia, there are already guidelines for implementing pharmaceutical care on hypertension. It shapes likely a pocketbook. The contents include the introduction of disease, epidemiology, aetiology, classification of hypertension, consequences of hypertension, diagnosis, management of hypertension 
and the roles and responsibilities of pharmacists in pharmaceutical care. The aim is that pharmacists can use this book as a reference in carrying out pharmaceutical care in hypertensive patients.

The implementation stage begins with conducting an assessment, followed by the preparation of a pharmaceutical service plan. Next is the implementation stage. This is done by communicating with doctors about prescribed drugs, then educating patients and their families according to the plans that have been prepared. The last stage is monitoring blood pressure, the possibility of organ damage, drug interactions and side effects, patient compliance with therapy and so on. (Anonim. 2006)

The application of pharmaceutical care in various countries is also not easy. Many obstacles were faced. In Indonesia, pharmaceutical care pocketbooks for hypertension are already exist. Pharmacists in hospitals, health centres and pharmacies can use it as a guide or reference source to play an active role in achieving optimal therapeutic outcomes for patients.

An article on pharmaceutical care in diabetes showed that the contribution of pharmacists in pharmaceutical care can improve the health and quality of life of patients (Ayadurai et al. 2016)). Other studies discussed the pharmaceutical care in mental disorders. If pharmaceutical care is carried out properly, it can increase patient compliance (Rubio-Valera, Chen, and O’Reilly 2014)

A literature review of research on the role of pharmacists in pharmaceutical services in patients with hypertension has been carried out (Ayu and Syaripuddin 2019). The research was conducted on articles published from 2010 to 2018 . The focus is on the interventions carried out by pharmacists and the resulting outcomes. In contrast to this research, where the aim is to examine the application of the pharmaceutical care concept that has been carried out by pharmacists in Indonesia. This study was conducted considering the cases of hypertension are still high. The number of pharmacists is increasing, the knowledge is increasing and research on hypertension is also increasing. Some hospitals already have pharmacists with clinical pharmacy expertise. It is time to assess how a guideline is being implemented.

\section{MATERIAL AND METHODS}

This research is a non-experimental study with a narrative review design that describes the implementation of pharmaceutical care in hypertension in Indonesia. Information was collected from various articles published in national journals. The year of publication is from 2014 to 2019 . The search is carried out using the keywords hypertension and pharmaceutical care. From the search, 13 articles were selected, but in the end, 1 article was excluded because the contents did not match the variables to be studied. 
In the selected articles, a study of the purpose, suitability of the topic, research methods used, sample size, and results of each article was conducted. The analysis was carried out on the variables of assessment, preparation of pharmaceutical service plans, implementation, and monitoring by comparing the data obtained by referring to the pharmaceutical care pocketbook on hypertensive desease (Anonim. 2006). The results are interpreted in the form of a narrative

\section{RESULT AND DISCUSSION}

Before conducting a more in-depth study of all the articles collected, it is first necessary to identify the general description or status of the articles. The information can be seen in Table 1.

Table 1. Article overview

\begin{tabular}{|c|c|c|c|c|c|c|}
\hline No & Resources & Research Design & $\mathrm{n}$ & Setting & Period & Reference \\
\hline 1 & $\begin{array}{l}\text { Pharmaceutical Journal of } \\
\text { Indonesia }\end{array}$ & $\begin{array}{c}\text { True } \\
\text { experimental }\end{array}$ & 79 & Drug store & 3 month & $\begin{array}{l}\text { Illahi, et al, } \\
\quad 2019\end{array}$ \\
\hline 2 & $\begin{array}{c}\text { Jurnal Farmasi Sains dan } \\
\text { Praktis }\end{array}$ & $\begin{array}{c}\text { Quasi } \\
\text { experimental }\end{array}$ & 30 & PHC & 4 month & $\begin{array}{l}\text { Utami., et al, } \\
2019\end{array}$ \\
\hline 3 & $\begin{array}{c}\text { Jurnal Farmasi Sains dan } \\
\text { Praktis }\end{array}$ & $\begin{array}{l}\text { Randomized } \\
\text { Pretest-Posttest }\end{array}$ & 50 & Hospital & 3 month & $\begin{array}{c}\text { Hernaeni et al, } \\
2019\end{array}$ \\
\hline 4 & Majalah Farmaseutik & $\begin{array}{c}\text { Quasi } \\
\text { experimental, }\end{array}$ & 78 & PHC & 2 month & $\begin{array}{l}\text { Wydiastuti et } \\
\text { al, } 2019\end{array}$ \\
\hline 5 & $\begin{array}{l}\text { Jurnal Kedokteran dan } \\
\text { Kesehatan Indonesia }\end{array}$ & $\begin{array}{c}\text { Quasi } \\
\text { expertimental }\end{array}$ & 60 & Hospital & 3 month & $\begin{array}{l}\text { Saputri, et al, } \\
2016\end{array}$ \\
\hline 6 & $\begin{array}{l}\text { Jurnal Sains Farmasi \& } \\
\text { Klinis }\end{array}$ & $\begin{array}{c}\text { Quasi } \\
\text { experimental }\end{array}$ & 68 & Hospital & 2 month & $\begin{array}{l}\text { Arizki and } \\
\text { Riza, } 2016\end{array}$ \\
\hline 7 & Jurnal Ilmiah Manuntung & $\begin{array}{c}\text { Quasi } \\
\text { experimental }\end{array}$ & 45 & Hospital & - & $\begin{array}{l}\text { Susanto and } \\
\text { Alfian, } 2015\end{array}$ \\
\hline 8 & $\begin{array}{l}\text { Jurnal Farmasi Klinik } \\
\text { Indonesia }\end{array}$ & $\begin{array}{c}\text { Quasi } \\
\text { experimental }\end{array}$ & 55 & Klinik & 2 month & $\begin{array}{l}\text { Dewi et al, } \\
\quad 2015\end{array}$ \\
\hline 9 & Folia Medica Indonesiana & Observational & 36 & Hospital & $\begin{array}{c}8 \\
\text { minggu }\end{array}$ & $\begin{array}{l}\text { Susilowaty et } \\
\text { al, } 2014\end{array}$ \\
\hline 10 & Media Farmasi & $\begin{array}{c}\text { Quasi } \\
\text { experimental }\end{array}$ & 60 & Hospital & 4 month & $\begin{array}{l}\text { Alfian et al, } \\
2014\end{array}$ \\
\hline 11 & Jurnal Farmasi Indonesia & $\begin{array}{c}\text { Randomized } \\
\text { Controlled Trial }\end{array}$ & 60 & Hospital & 3 month & $\begin{array}{l}\text { Sitepu et al, } \\
2014\end{array}$ \\
\hline 12 & $\begin{array}{l}\text { Jurnal Manajemen dan } \\
\text { Pelayanan Farmasi }\end{array}$ & $\begin{array}{c}\text { Quasi } \\
\text { experimental. }\end{array}$ & 87 & Hospital & 1 month & $\begin{array}{l}\text { Mika et al, } \\
2014\end{array}$ \\
\hline
\end{tabular}


Table 2. The results of a review of the stages of pharmaceutical care

\begin{tabular}{|c|c|c|c|c|c|c|}
\hline No. & Resources & Step I & Step II & Step III & Step IV & Reference \\
\hline 1 & $\begin{array}{l}\text { Pharmaceutical Journal of } \\
\text { Indonesia }\end{array}$ & No & No & Yes & Yes & $\begin{array}{l}\text { Illahi, et al, } \\
2019\end{array}$ \\
\hline 2 & $\begin{array}{l}\text { Jurnal Farmasi Sains and } \\
\text { Praktis }\end{array}$ & No & No & Yes & Yes & $\begin{array}{l}\text { Utami., et al, } \\
2019\end{array}$ \\
\hline 3 & $\begin{array}{l}\text { Jurnal Farmasi Sains and } \\
\text { Praktis }\end{array}$ & No & No & Yes & Yes & $\begin{array}{c}\text { Hernaeni et al, } \\
2019\end{array}$ \\
\hline 4 & Majalah Farmaseutik & No & No & Yes & Yes & $\begin{array}{l}\text { Wydiastuti et } \\
\text { al, } 2019\end{array}$ \\
\hline 5 & $\begin{array}{l}\text { Jurnal Kedokteran and } \\
\text { Kesehatan Indonesia }\end{array}$ & No & Yes & Yes & Yes & $\begin{array}{l}\text { Saputri, et al, } \\
2016\end{array}$ \\
\hline 6 & $\begin{array}{llll}\text { Jurnal } & \text { Sains Farmasi \& } \\
\text { Klinis } & & & \end{array}$ & No & No & Yes & Yes & $\begin{array}{l}\text { Arizki and } \\
\text { Riza, } 2016\end{array}$ \\
\hline 7 & Jurnal Ilmiah Manuntung & No & No & Yes & Yes & $\begin{array}{l}\text { Susanto and } \\
\text { Alfian, } 2015\end{array}$ \\
\hline 8 & $\begin{array}{l}\text { Jurnal Farmasi Klinik } \\
\text { Indonesia }\end{array}$ & No & No & Yes & Yes & $\begin{array}{l}\text { Dewi et al, } \\
2015\end{array}$ \\
\hline 9 & Folia Medica Indonesiana & No & No & Yes & Yes & $\begin{array}{l}\text { Susilowaty et } \\
\text { al, } 2014\end{array}$ \\
\hline 10 & Media Farmasi & No & No & Yes & Yes & $\begin{array}{l}\text { Alfian et al, } \\
2014\end{array}$ \\
\hline 11 & Jurnal Farmasi Indonesia & No & No & Yes & Yes & $\begin{array}{l}\text { Sitepu et al, } \\
2014\end{array}$ \\
\hline 12 & $\begin{array}{l}\text { Jurnal Manajemen and } \\
\text { Pelayanan Farmasi }\end{array}$ & No & No & Yes & Yes & $\begin{array}{l}\text { Mika et al, } \\
2014\end{array}$ \\
\hline
\end{tabular}

Eleven of the articles used experimental research methods, only one article was non-experimental. The research was conducted in various settings, mostly in hospitals with eight articles, the rest was in pharmacies and health centres.

Furthermore, the review process is continued at the stage of implementing pharmaceutical care. In the pocketbook, it is written that the stages begin with assessment (Phase I), then the preparation of service plans (Phase II), implementation of the plan (Phase III) and the last is monitoring (Phase IV). The results of the review of the stages of pharmaceutical-care implementation in 12 articles are presented in table 2. In all articles, there is no assessment stage. There are only identifying patient characteristics in general, such as age, gender, education, and so on. Meanwhile, according to the pharmaceutical care pocketbook on hypertension, at this stage of the assessment, the pharmacist prepares a database 
specifically for each patient, from medical history, social history and drug therapy being carried out. However, there is no one article that reports on the incidence of drug-related-problems (DRPs), such as side effects, overdose, sub-therapeutic dosing, inappropriate drug selection and drug interactions.

A part of all was not conducting an assessment. All articles also did not prepare a service plan to be implemented in this pharmaceutical care. The pharmaceutical service plan may include a plan of activity objectives. For example, slowing down complications, increasing patient compliance, preventing problems arising from drug therapy and so on. In the pharmaceutical service plan, pharmacists provide advice on drug selection, replacement or alternative drugs, dose changes and drug regimens.

The assessment and preparation of this service plan must be done individually because each has different characteristics. It takes sufficient time to be able to do both of these stages. The research in this article was only carried out for 3 to 4 months, some even for only 1 month. A study in Brazil, which was conducted by collecting data retrospectively from 2006 to 2012, was conducted in 2013. The application of pharmaceutical care was carried out for one year at the primary service level. Pharmacists perform pharmaceutical care for 104 hypertensive patients. Clinical indicators that are targeted for monitoring are systolic and diastolic blood pressure, triglycerides, and cholesterol. Good total cholesterol, low density lypho-protein (LDL) and high density lypho-protein (HDL). The data analysis was carried out according to the period 2006 - 2008, as pre-pharmaceutical care, 2009 was the phase of pharmaceutical care implementation and 2010-2012 after the implementation of pharmaceutical care. The result is the achievement of systolic blood pressure reaching 54.4\%, diastolic $79.0 \%$ and total cholesterol reaching the target of $27.3 \%$. In the period before the application of pharmaceutical care. In the period after the implementation of pharmaceutical care, the results were $93 \%$ for systole and diastole, and $60.0 \%$ for total cholesterol (De Souza Cazarim et al. 2016)

The next stage in pharmaceutical care is intervention. Interventions are provided in various forms of activities. Direct counselling is the most common form of implementation carried out by pharmacists (Aryzki and Alfian 2016); (Saputri, Akrom, and Darmawan 2016); (Dewi, Sari, and Probosuseno 2015); (Aryzki and Alfian 2016); (Sitepu, Harahap, and Nasution 2014). None of the articles describes in detail the form of counselling provided. Other activities include distributing leaflets (Susanto and Alfian 2015); (Widyastuti, Yasin, and Kristina 2019), sending short messages/SMS (Saputri et al. 2016), placing medicine in pillboxes (Illahi, Hariadini, and Pramestutie 2019).

According to Brata and Azizah (Brata and Azizah 2018), most pharmacists showed their awareness of the implementation of pharmaceutical care. However, the lack of uniformity in pharmacist responses to questions about the primary focus of pharmaceutical care and its objectives indicates a degree of confusion and a lack of awareness and appropriate formal training on this issue. The declaration by the 
majority of those who are aware of the pharmaceutical services they have implemented and maintained in practice requires further examination. In the implementation process, other processes should be carried out by the pharmaceutical care pocketbook for hypertension, implementation itself is an activity to implement a pharmaceutical service plan that should have been prepared previously. These activities include starting drug therapy, educating patients, educating patients' families, etc. Pharmacists work with patients to maximize understanding and involvement in the pharmaceutical plan, then note the steps that have been taken, and any obstacles that need to be corrected during the treatment process (Anonim. 2006). Based on the results of this study, it can be said that the majority of pharmacists have implemented it in the form of counselling, but have not fully referred to the pharmaceutical care pocketbook on hypertension.

The last stage in the pharmaceutical-care cycle is monitoring the outcome of the intervention. Monitoring is carried out on important matters, such as blood pressure such as organ damage after treatment, namely the heart, kidneys, eyes and brain, as well as monitoring drug interactions and side effects after implementation. In addition, monitoring of knowledge, medication adherence was also carried out.

In this article, the most monitoring is done on knowledge, compliance and blood pressure. Monitoring carried out by pharmacists in the pharmaceutical care process shows positive results from the implementation of pharmaceutical care to patients, both from the results of monitoring compliance or monitoring blood pressure. Compliance monitoring showed significant changes in patient compliance. The average systolic blood pressure before pharmaceutical care was $150 \mathrm{mmHg}$, and $131 \mathrm{mmHg}$ after pharmaceutical care, with a diastolic blood pressure of $95 \mathrm{mmHg}$ before pharmaceutical care was performed. and $83 \mathrm{mmHg}$ after pharmaceutical care, then the range of reduction in systolic blood pressure was $18 \mathrm{mmHg}$ and a decrease in diastolic blood pressure was $12 \mathrm{mmHg}$ (Utami, Rahajeng, and Soraya 2019).

Based on the results of a review of all articles, after pharmaceutical care was carried out, and blood pressure monitoring was carried out, it was found that the average range of decrease in systolic blood pressure was 14.125 after pharmaceutical care, and the average range of decrease in diastolic blood pressure was 9.25 after pharmaceutical care. However, the timing of monitoring carried out by several pharmacists has differences and is not by the pharmaceutical care pocketbook for hypertension which requires blood pressure monitoring to be carried out 2 to 4 weeks after therapy (Anonim. 2006)

The result of the study is that the assessment is only limited to age and gender, and not like the concept of pharmaceutical care. No one made a plan. Most of the implementations are only counselling. No one has contacted the doctor to clarify or modify the prescription. Monitoring is carried out to measure the 
effectiveness of therapy, as well as to measure the impact of pharmaceutical care on hypertension. The results of the study show that the articles reviewed have carried out monitoring, which is mostly in the form of monitoring blood pressure and monitoring patient compliance, but no articles have been found that indicate monitoring of target organ damage after medication, as well as drug interactions and side effects, which are things that must also be monitored in the implementation of pharmaceutical care according to the pharmaceutical care pocketbook for hypertension.

Based on the results of this study, it can be said that the majority of pharmacists have carried out monitoring in the form of monitoring blood pressure and compliance, but have not fully referred to the pharmaceutical care pocketbook on hypertension. According to the results of the study, it was found that the majority of the implementation of pharmaceutical care in hypertension in Indonesia was carried out by assessment, implementation, and monitoring, but the preparation of pharmaceutical service plans was not often carried out. The majority of the implementation of pharmaceutical care places more emphasis on implementation or practice, in the form of counselling by pharmacists, but does not fully follow the pharmaceutical care pocketbook on hypertension issued by the Ministry of Health in 2006. The process of preparing a pharmaceutical service plan related to patient needs with drugs. Then, solving drug therapy problems through an organized and prioritized process, based on the patient's medical condition, risk and severity. This process is often overlooked and more focused on its intervention, mostly in the form of counselling. This can happen due to various factors, such as the quality of pharmacists and pharmacist competencies. It reguires training and continuous education with a curriculum that supports clinical pharmacy services. In addition, the communication skills of pharmacists with other health professions are still lacking because there are still limited opportunities for this.

A study was conducted in China involving 292 hospitals from 23 provinces. In this study, there were 740 clinical pharmacists, 1298 doctors and 778 supplying pharmacists, which included 3096 patients. The research objective is about the current status of pharmaceutical care in China. The result is that China has made progress in the application of pharmaceutical care. Checks on doctor's prescriptions, service plans, discussions and collaborations between clinical pharmacists and doctors and pharmacists who provide drugs have been going well. Patients are satisfied with the pharmaceutical care services provided. What is still lacking is that there is no payment calculation for pharmaceutical care, because there is no performance appraisal system for it (Guo et al. 2020). Indonesia also does not have a regulation that regulates the number of payments either from patients or health insurance managers to pharmacists who carry out pharmaceutical care. 
As in China, in Malaysia, research was conducted on pharmaceutical care. A total of 420 community pharmacists who were respondents there conducted health screening and monitoring (99.5\%), selected and recommended health supplements (90.5\%), reviewed medication (68.8\%), weight management (52) $4 \%$ ) and smoking cessation counselling (51.0\%). More than half (53.3\%) of the respondents reported that they provide pharmaceutical care services to patients with chronic diseases. An implementation that follows pharmaceutical care guidelines is still relatively small. namely conducting an assessment through collecting patient data $(23.3 \%)$ and evaluating medical information (18.6\%). Then formulate a drug therapy plan (9.3\%), and implement the drug therapy plan (4.5\%). The last stage is monitoring and modifying the therapy plan as much as $18.3 \%$ (Loh, Chua, and Karuppannan 2021).

\section{CONCLUSION}

The implementation of pharmaceutical care in Indonesia has not fully followed the stages as recommended in the pocketbook. Pharmacists was seem to ignore the stages of assessment and preparation of pharmaceutical service plans that will be implemented. The assessment is only limited to general characteristics, not individual. While at the implementation stage, there is still more patient focus through counselling and leaflets. Communication and suggestions to modify or even replace the drugs prescribed by doctors are almost non-existent. However, the positive value is that, although the implementation of pharmaceutical care has not followed the guidelines in the pocketbook, all articles report good outcomes in its monitoring. Compliance and patient knowledge increased, blood pressure was controlled and patient satisfaction increased. Suggestions from this research for professional organizations is to guide pharmacists to improve their services through pharmaceutical care. Regulators are expected to be able to develop more practical and simpler guidelines so that it will be easier to follow.

\section{ACKNOWLEDGEMENT}

Thank you to the head of the Department of Pharmacy who has supported this research.

\section{CONFLICT OF INTEREST}

All authors declare there is no conflict of interest in this manuscript.

\section{REFERENCES}

Anonim. 2006. Pharmaceutical Care Untuk Penyakit Hipertensi, Direktorat Bina Farmasi Komunitas Dan Klinik DITJEN Bina Kefarmasian Dan Alat Kesehatan Departemen Kesehatan Republik Indonesia. Jakarta.

Aryzki, Saftia, and Riza Alfian. 2016. "Pengaruh Brief Counseling Terhadap Aktifitas Fisik Pada Pasien Hipertensi Di RSUD Dr. H. Moch Ansari Saleh Banjarmasin.” Jurnal Sains Farmasi \& Klinis 3(1):84. doi: $10.29208 /$ jsfk.2016.3.1.104. 
Ayadurai, Shamala, H. Laetitia Hattingh, Lisa B. G. Tee, and Siti Norlina Md Said. 2016. “A Narrative Review of Diabetes Intervention Studies to Explore Diabetes Care Opportunities for Pharmacists." Journal of Diabetes Research 2016(1). doi: 10.1155/2016/5897452.

Ayu, Galih Ajeng, and Muhamad Syaripuddin. 2019. "Peranan Apoteker Dalam Pelayanan Kefarmasian Pada Penderita Hipertensi." Jurnal Kedokteran Dan Kesehatan 15(1):10. doi: 10.24853/jkk.15.1.10-21.

Brata, Andy, and Lailan Azizah. 2018. "Analysis of Pharmaceutical Care Services in Hospital Pharmacy Installation in Jambi City.” Jurnal Bahana Kesehatan Masyarakat 2(2):113-17.

Dewi, Melani, Ika P. Sari, and Probosuseno. 2015. "The Influence of the Pharmacists Counseling on Patient Adherence and Hypertension Control on Patient of Prolanis at Mitra Husada Clinics." Indonesian Journal of Clinical Pharmacy 4(4):242-49. doi: 10.15416/ijcp.2015.4.4.242.

Guo, Xiaobo, Dongning Yao, Jie Liu, Yuankai Huang, Yitao Wang, and Wenbing Yao. 2020. "The Current Status of Pharmaceutical Care Provision in Tertiary Hospitals: Results of a CrossSectional Survey in China.” BMC Health Services Research 20(1):1-9. doi: 10.1186/s12913020-05371-7.

Illahi, Ratna Kurnia, Ayuk Lawuningtyas Hariadini, and Hananditia Rachma Pramestutie. 2019. "Efektivitas Home Pharmacy Care Dalam Meningkatkan Pengetahuan Dan Kepatuhan Terhadap Pengobatan Pasien Hipertensi (Studi Dilakukan Selama 3 Bulan Di Apotek Kota Malang)." Pharmaceutical Journal Of Indonesia 5(1):21-28.

Loh, Pengyeow, Siew Siang Chua, and Mahmathi Karuppannan. 2021. "The Extent and Barriers in Providing Pharmaceutical Care Services by Community Pharmacists in Malaysia: A CrossSectional Study." BMC Health Services Research 21(1):1-14. doi: 10.1186/s12913-021-068207.

Rubio-Valera, Maria, Timothy F. Chen, and Claire L. O’Reilly. 2014. "New Roles for Pharmacists in Community Mental Health Care: A Narrative Review." International Journal of Environmental Research and Public Health 11(10):10967-90. doi: 10.3390/ijerph111010967.

Saputri, Ginanjar Zukhruf, Akrom Akrom, and Endang Darmawan. 2016. "Counseling and Motivational Short Text Messages Increase Adherence and Behavioral Changes in Patient with Hypertension." Jurnal Kedokteran Dan Kesehatan Indonesia 7(3):87-94. doi: 10.20885/jkki.vol7.iss3.art3. 
Sitepu, Nadroh, Urip Harahab, and Salli Nasution. 2014. "Evaluasi Asuhan Kefarmasian Terhadap Hasil Terapi Dan Kualitas Hidup Pasien Hipertensi Primer Di Rumah Sakit.” Jurnal Farmasi Indonesia 07(1):42-49.

De Souza Cazarim, Maurílio, Osvaldo De Freitas, Thais Rodrigues Penaforte, Angela Achcar, and Leonardo Régis Leira Pereira. 2016. "Impact Assessment of Pharmaceutical Care in the Management of Hypertension and Coronary Risk Factors after Discharge." PLoS ONE 11(6):2006-8. doi: 10.1371/journal.pone.0155204.

Susanto, Yugo, and Riza Alfian. 2015. "Perbaikan Perilaku Dan Tekanan Darah Pasien Hipertensi." 1(2):140-44.

Upadhyay, Dinesh K., and Guat See Ooi. 2018. Enhancing Quality of Patient-Centered Care Services in Developing Countries: Pharmaceutical Care Approach. Elsevier.

Utami, Pinasti, Bangunawati Rahajeng, and Cindy Soraya. 2019. "Pengaruh Edukasi Home Pharmacy Care Terhadap Kualitas Hidup Pasien Hipertensi Di Puskesmas (Effect Of Education Home Pharmacy Care On Hypertension Patients Living Quality In Puskesmas), Jurnal Farmasi Sains Dan Praktis 5(1):41-51.

Widyastuti, Sad, Nanang Munif Yasin, and Susi Ari Kristina. 2019. "Pengaruh Home Pharmacy Care Terhadap Pengetahuan, Kepatuhan, Outcome Klinik Dan Kualitas Hidup Pasien Hipertensi.” Majalah Farmaseutik 15(2):105. doi: 10.22146/farmaseutik.v15i2.47623. 